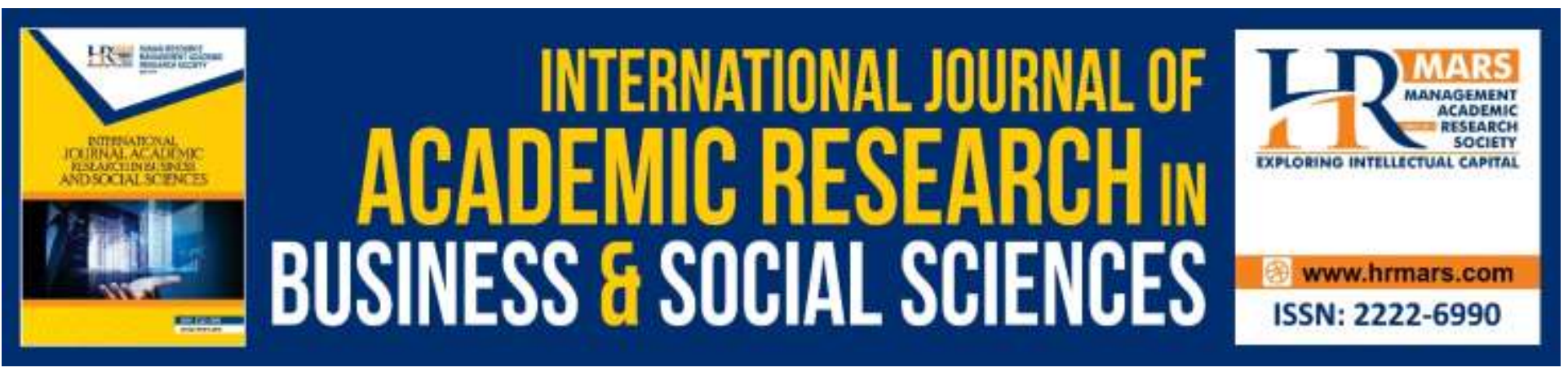

\title{
The Juxtaposition of Artistic Elements and Creation Principles in Scenography Invention of Theatre Productions in Malaysia Art School, Johor
}

Zolkipli Abdullah, Syahrul Azlina Sikandar

To Link this Article: http://dx.doi.org/10.6007/IJARBSS/v10-i2/6986

DOI:10.6007/IJARBSS/v10-i2/6986

Received: 23 January 2020, Revised: 08 February 2020, Accepted: 15 February 2020

Published Online: 29 February 2020

In-Text Citation: (Abdullah \& Sikandar, 2020)

To Cite this Article: Abdullah, Z., \& Sikandar, S. A. (2020). The Juxtaposition of Artistic Elements and Creation Principles in Scenography Invention of Theatre Productions in Malaysia Art School, Johor. International Journal of Academic Research in Business and Social Sciences, 10(2), 742-747.

\section{Copyright: (C) 2020 The Author(s)}

Published by Human Resource Management Academic Research Society (www.hrmars.com)

This article is published under the Creative Commons Attribution (CC BY 4.0) license. Anyone may reproduce, distribute, translate and create derivative works of this article (for both commercial and non-commercial purposes), subject to full attribution to the original publication and authors. The full terms of this license may be seen

at: http://creativecommons.org/licences/by/4.0/legalcode

Vol. 10, No. 2, 2020, Pg. 742 - 747

Full Terms \& Conditions of access and use can be found at http://hrmars.com/index.php/pages/detail/publication-ethics 


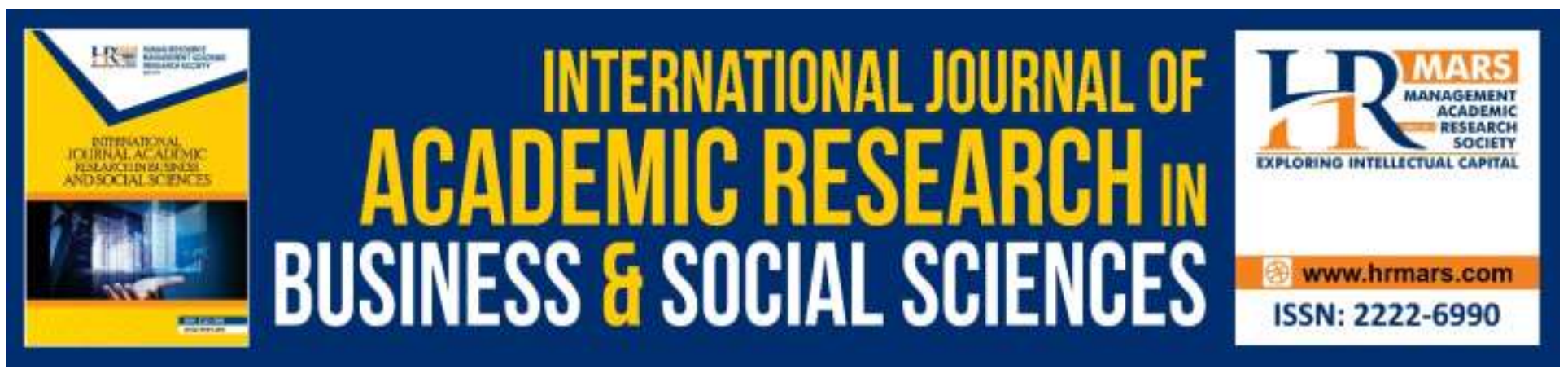

\title{
The Juxtaposition of Artistic Elements and Creation Principles in Scenography Invention of Theatre Productions in Malaysia Art School, Johor
}

\author{
Zolkipli Abdullah, Syahrul Azlina Sikandar \\ Department of Performing Arts, Faculty of Music and Performing Arts, Sultan Idris Education \\ University, Malaysia
}

\begin{abstract}
The juxtaposition of artistic elements and creation principles in the scenography invention within the creative and artistic pieces work together and are important components in the theatrical processes in a theatre production. This is because scenography components combine the elements of visual creations, arts and creative ideas in abstract, realistic and experimental following the concept and theme of the staged play. This research was conducted using qualitative method, guided by the data collected in the theatrical works produced by artistic productions along with the teaching and learning curriculum on scenography element towards 20 students and 2 teachers. Thus, research shows the effective role of scenography invention in producing a theatre production in Malaysia Art School, Johor which implemented teaching and learning patterns focusing on the development of creative and innovative thinking through exploration activities to produce high quality ideas and creations. Furthermore, it also exhibits the factors which influenced scenography teaching and learning issues in a production. The result of this research displays the significance of juxtaposition of artistic elements and creation principles in the invention of creative scenography works through exploration approach to ensure the understanding of artistic elements and creation principles elaboration among the teachers and students be exposed within the earlier stages in a theatre production.
\end{abstract}

\section{Introduction}

The implementation of creative and innovative elements in the education in Malaysia School of Art will catalyse the country's transformation agenda and they work alongside each other so that the process is applied in teaching and learning. Scenography learning in general is to build creativity ability of a student in producing creative artworks in scenography. Scenography is closely-related to visual arts which carries the meaning of visual literacy, covering the ability to use visual languages to read and appreciate visual images. Scenography is one of the main components in a theatrical 
production especially since it contributes to the collection of creations and ideas from artists and their production members.

This research will study on the implementation of artistic elements and creation principles in the invention of scenography in theatre productions by the upper secondary students in Malaysia Art School, Johor. This research is able to identify the important aspects which need to be highlighted are the artistic elements and creation principles in scenography invention on the creative artworks of theatre productions in every stage, and they will help in producing effective teaching and learning processes to ensure every staged theatre has the artistic values of scenography.

Promoting understanding on the importance of artistic elements and creation principles in scenography invention in theatre productions by Malaysia Art School, Johor students, exposing and improving the understanding of the teachers on the significance of scenography invention in the upper secondary theatre productions' processes, sharing useful knowledge among teachers and production team to help in producing impactful processes of creation and clear images of scenography visual in cultivating the students' potential and talent holistically for theatre productions that contain the artistic values and producing work procedure for the teachers on the importance of strengthening the application of artistic elements and creation principles in scenography invention on the processes creating theatre productions.

\section{Objective}

The objectives of this research are to investigate whether artistic elements and creation principles in scenography invention can be implemented in the teaching and learning as well as identifying whether its function can produce a dynamic support system to the students in the process of cultivating every individual's potential and talent holistically through theatre productions. Apart from that, to identify the influential factors of teaching and learning issues in scenography within the theatre productions by Malaysia Art School, Johor.

\section{Methodology}

This research is conducted through qualitative method guided with data collection, content and material analysis founded will comprise of upper secondary artistic production theatre artworks and teaching and learning curriculum of scenography component in Malaysia Art School, Johor. This research uses interview approach, document review, survey, observation and field research. Through these methods, the collected data will be in the form of words, illustrations, photos, magazines, books, field notes and other relevant forms. The information collection in this research focuses on the data produced through thoroughly-planned processes. This research is conducted on 20 students and 2 teachers. Through this research, researchers use theories from Pierce for the theoretical analysis. According to Aart van Zoest (1978); Khalid, Islam \& Ahmed (2019); Alzgool (2019); Umrani, Ahmed \& Memon (2015) by adapting Pierce' opinion, there are three (3) categories by focusing on three (3) stages which are Firstness, Secondness and Thirdness. The processes of scenography creation include the stages of cognitive, psychomotor and effective product, in which will ensure the end product to achieve the wants and needs of a quality performance from any theatre production. The main process of the scenography creation in theatres comprises of the strategies and contents 
INTERNATIONAL JOURNAL OF ACADEMIC RESEARCH IN BUSINESS AND SOCIAL SCIENCES

Vol. 10, No. 2, Feb, 2020, E-ISSN: 2222-6990 @ 2020 HRMARS

such as information, research, the shaping and development of ideas, exploration, synthesis and creation, as well as evaluation.

\section{Findings}

The art curriculum in Malaysia Art School has the purpose of building and expanding students' potential from the aspects of creativity and appreciation ability towards theatrical arts. This curriculum is an extended program for the students who chose theatre as their major in Forms 4 and 5. The subjects focus on theatre practical skills and producing theatre works. Students are involved with various theatrical activities such as script writing, evaluating works and staging plays. These experiences intend to encourage the development of creative and critical thinking skills among the students. Artistic elements and creation principles in the invention of scenography focus on enhancing creative and innovative thinking skills among the students through exploration activities. Exploration activities such as text research, visual research, space research, along with sound and special effects research were conducted in order to obtain various information to visualise ideas and concepts of scenography creation.

The exploration on text research was carried out to gain information such as the society's background, period and time settings, and social and socio-culture statuses. Visual research aims to obtain information on suitable images based on the ideas and concepts of scenography. The findings on space research can be used to make plans on actors' movements and manage the use of set and props according to the suitability of the acting space. The research on sound and special effects and their suitability was conducted to prepare a list and collection of sounds and special effects to be used appropriately. In addition to that, exploration activities in creating set through the juxtaposition of artistic elements, creation principles and 2-dimensional (2D) and 3-dimensional (3D) designs. Exploration in various media forms such as digital media, photography, video, magazines and newspapers also help to obtain information and ideas in producing scenography invention in students' creative artworks through theatre productions.

In general, scenography exploration activities intend to produce a juxtaposition of artistic elements and creation principles for theatre productions. Its activities are based on practical activities using hands-on approaches. There are various approaches that can be used to draft their teaching to achieve specified learning standards. These approaches are the teachers' strategies to achieve the objectives of their lesson plans. Inquiry-based learning is one of the teaching and learning methods which is student-centred, involving inquiries and curiosity in which the students need to find answers through observation, hypothesis, data collection, measurement, translation and making summaries. Inquiries are also a process in creative inventions which encourage problem-solving, exploration and discovery as well as deep understanding on any given task.

In the context of creative artworks and scenography invention through theatre productions, students need to be exposed more to the related products that implemented the element of scenography from various sources. In learning processes, a lot of questions may arise. For example, "What are the appropriate designs for set and props to show the living room?" and "What are the suitable sound effects to show the situation during the night?". Students will find the answers to their questions through a discussion with the teachers as well as finding information from various sources. 
Apart from that, teachers also did not fully understand the meaning of scenography inventions in stage plays (theatre productions), thus they are unable to focus specifically on this aspect. Hence, the students are also negatively impacted and this will continue until the students further their studies into higher institutions. Time restriction is also a reason as to why the teachers failed to deliver knowledge on aesthetical aspects on scenography invention to the students to be implemented in theatre productions. This happens because the teachers in schools need to complete the syllabus before the school ends.

In general, the success of a subject depends on the approach and methods applied. If the implementation is not carried out correctly, it will give a huge impact on the students. The shallow understanding on the concept of scenography appreciation will result in the fallout of the purpose of art curriculum (scenography) in theatre productions in Malaysia Art School, Johor. The failure of scenography teachers to understand and interpret the purposes, objectives and contents through appropriate approaches and methods are the main factors causing the aspects of the juxtaposition of artistic elements and creation principles in the scenography inventions in theatre productions to be deemed unimportant. This assumption will forever be a stigma to the subjects that are supposed to help the students' development from the aspects of cognitive and psychomotor in creating creative artworks in theatre productions.

\section{Conclusion}

Scenography is very closely-related to visual arts, and reading visual languages is the most important instrument in producing visuals on stage. Through this visualisation process, a scenographer needs excellent visual observations such as photography, reality and sighting experience (Pamela, 2009; Muhammad, Saoula, Issa \& Ahmed, 2019). The process of interpreting visuals from works require complex imagination and creativity since the existence of visuals on stage needs the chemistry between the work and the characterisation, and most importantly, these visuals can be accepted logically and comprehensible not just by the audience but also the production members. The purpose of the development of creativity and innovation among the students in Malaysia Art School through scenography teaching and learning is to produce creative and innovative individuals in theatre productions.

Creativity development conducted during the exploration processes has shown creativity in set creation through the elements of creation principles, artistic, and 2D and 3D designs. This is because identifying scenography elements implemented in teaching and learning aims to produce a dynamic support system towards the students. The process of cultivating individual potential and talents holistically through theatre productions will enable the students to elaborate on the functions of scenography element and able to find representations involving more standardised basics, techniques and criteria. Theatre productions will also display the students' abilities in implementing artistic elements and creation principles in scenography invention, identifying the factors that influence the issues on the teaching and learning of scenography in theatre productions among the students in Malaysia Art School, Johor. 
INTERNATIONAL JOURNAL OF ACADEMIC RESEARCH IN BUSINESS AND SOCIAL SCIENCES Vol. 10, No. 2, Feb, 2020, E-ISSN: 2222-6990 @ 2020 HRMARS

\section{Acknowledgement}

This paper is based on the research project entitled 'Implementation of Scenography Elements in the Production of' Creative Arts among Upper Secondary Students through Theatrical Production in the Malaysia Arts School of Johor'. The authors would like to extend their gratitude to the Research Management and Innovation Centre (RMIC), Sultan Idris Education University (UPSI) for the University Research Grants (code: 2018-0016-107-10) that helped fund (RM 8,788.00) the research.

\section{References}

Alzgool, M. (2019). Nexus between green HRM and green management towards fostering green values. Management Science Letters, 9(12), 2073-2082.

Aronson, A. (2017). The routledge companion to scenography. New York: The Routledge

Barret, M. (1982). Art education: a strategy for course design. London: Heinneman Educational Books.

Boges, S. (2015). Liquid spaces: scenography, installations and spatial experiences. New York: Gestalten.

Davis, J. (2016). Foundation of design. Arizona: Tempe Digital LLC

Gardner, H. (1983). Frames of mind: a theory of multiple intelligences. New York: Basic Books.

Khalid, N., Islam, D. M. Z., \& Ahmed, M. R. M. (2019). SENTREPRENEURIAL TRAINING AND ORGANIZATIONAL PERFORMANCE: IMPLICATIONS FOR FUTURE. Humanities \& Social Sciences Reviews, 7(2), 590-593.

Muhammad, K., Saoula, O., Issa, M., \& Ahmed, U. (2019). Contract management and performance characteristics: An empirical and managerial implication for Indonesia. Management Science Letters, 9(8), 1289-1298.

Pamela, H. (2009). What is scenography. London: Routledge.

Pantouvaki, S. (2010). Visualising theatre studies: scenography from concept to design realisation mapping minds. Monika Raech: IDP

Umrani, W., Ahmed, U., \& Memon, P. (2015). Examining the absorptive capacity construct: A validation study in the Pakistani banking context. Management Science Letters, 5(12), 10531058. 